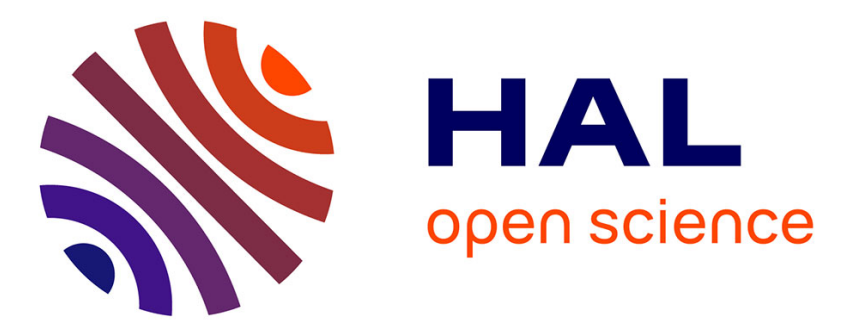

\title{
Geology and climate conditions affect more humus forms than forest canopies at large scale in temperate forests
}

Jean-François Ponge, Bernard Jabiol, Jean-Claude Gégout

\section{To cite this version:}

Jean-François Ponge, Bernard Jabiol, Jean-Claude Gégout. Geology and climate conditions affect more humus forms than forest canopies at large scale in temperate forests. Geoderma, 2011, 162 (1-2), pp.187-195. 10.1016/j.geoderma.2011.02.003 . hal-00578552

\section{HAL Id: hal-00578552 \\ https://hal.science/hal-00578552}

Submitted on 21 Mar 2011

HAL is a multi-disciplinary open access archive for the deposit and dissemination of scientific research documents, whether they are published or not. The documents may come from teaching and research institutions in France or abroad, or from public or private research centers.
L'archive ouverte pluridisciplinaire HAL, est destinée au dépôt et à la diffusion de documents scientifiques de niveau recherche, publiés ou non, émanant des établissements d'enseignement et de recherche français ou étrangers, des laboratoires publics ou privés. 


\section{Geology and climate conditions affect more humus forms than forest}

\section{2 canopies at large scale in temperate forests}

3 Jean-François Ponge ${ }^{\mathrm{a},{ }^{*}}$, Bernard Jabiol ${ }^{\mathrm{b}}$, Jean-Claude Gégout ${ }^{\mathrm{b}}$

$4 \quad{ }^{a}$ Muséum National d'Histoire Naturelle, CNRS UMR 7179, 4 avenue du Petit-Château, 91800

5 Brunoy, France

${ }^{b}$ AgroParisTech, INRA UMR 1092, Laboratoire d'Etude des Ressources Foret Bois (LERFoB), ENGREF, 14 rue Girardet, 54042 Nancy Cedex, France

ABSTRACT

We investigated by linear gradient analysis (RDA) the relationships between forest humus forms ( 9

humus forms and the Humus Index) and 148 variables describing geology, climate, soil type, geography and the floristic composition of forest canopies, using 3441 plots of the EcoPlant database covering the whole French territory. Among these variables, geology (alkaline vs acidic substrate) and climate (warm/dry vs cold/rainy) were the major determinants of humus forms, scaling mull humus forms from eumull to dysmull and opposing them to mor/moder, while the contribution of tree canopies was negligible. This trend was verified by partial RDA with environment or abundance of tree species from forest canopy as co-factors. The original position of amphi was confirmed: it was the only humus form not included in the gradient of increasing biological activity ordinated according to climate and geology. Results and possible forecasts of humus forms according to global warming were discussed to the light of existing knowledge.

Keywords: EcoPlant database, humus form, Humus Index, parent rock, soil type, climate, geography, RDA

\footnotetext{
* Corresponding author. Muséum National d'Histoire Naturelle, CNRS UMR 7179, 4 avenue du Petit-Château, 91800 Brunoy, France. Tel. +33 6 78930133; fax: +33 1 60465719. E-mail address: ponge@ mnhn.fr (J.F. Ponge).
} 


\section{Introduction}

The humus form, i.e. the vertical arrangement of organic matter in topsoil horizons, is known to be influenced by biotic (litter amount and quality, soil-dwelling microbial and animal communities) and abiotic factors (climate, parent rock, soil type) according to a variety of key processes which have been reviewed by Ponge (2003). While abiotic factors such as regional climate and geology cannot be back-influenced by humus forms, at least in the short-term (but see Van Breemen, 1993; Marland et al., 2003), biotic factors are tightly linked to humus forms according to feed-back loops (Perry, 1995; Wardle and Lavelle, 1997; Ponge et al., 1999), making distal and proximal causes hard to discern and thus any predictions hardly questionable. In forests, past land use (Koerner et al., 1997; Dupouey et al., 2002) and present-day management options (Hölscher et al., 2001; Godefroid et al., 2005; Van Calster et al., 2007) are known to influence humus forms at the scale of management units. At a more local scale individual trees (Boettcher and Kalisz, 1990; Kuuluvainen et al., 1994; Peltier et al., 2001), forest vegetation (Bernier et al., 1993; Emmer, 1994; Bernier and Ponge, 1994), microtopography (Dwyer and Merriam, 1981) and animal/microbial populations (Gourbière, 1983; Wilcox et al., 2002) stem in a pronounced variation of humus forms and ground floor thickness (Arp and Krause, 1984; Riha et al., 1986; Aubert et al., 2006).

Soil types and humus forms do not vary at the same scale of time (Crocker and Major, 1955; Switzer et al., 1979; Turk et al., 2008), making their causal relationships highly variable in space and time, more especially in forest environments (Kuuluvainen et al., 1993; Ponge et al., 1998, 1999). It has been shown that the thickness of forest floor and the structure of organo-mineral horizons, which are under the paramount influence of ecosystem engineers such as earthworms (Hoogerkamp et al., 1983; Bernier, 1998; Wironen and Moore, 2006; but see Burghouts et al., 1998), can vary according to the age of trees (Aubert et al., 2004; Godefroid et al., 2005; Chauvat et al., 2007), plant successional processes (Leuschner et al., 1993; Emmer and Sevink, 1994; Scheu and Schulz, 1996) and undergo cycles at the scale of centuries in naturally regenerating late-successional forests (Bernier and Ponge, 1994; Sagot et al., 1999; Salmon et al., 2008). Litter quality, resulting from the species composition of forest vegetation (Wolters, 1999; Loranger et al., 2002; Wardle et al., 2003) and conditions of tree 
growth (Northup et al., 1995; Hättenschwiler et al., 2003), is known to influence and be influenced by humus forms and associated soil trophic networks (Davies et al., 1964; Nicolai, 1988; Ponge et al., 1999). At last, forest vegetation is locally selected (filtered out from regional pools of species) by forest floor and topsoil properties, combined with species interactions (Daniel and Schmidt, 1972; Goldberg, 1982; Falkengren-Grerup and Tyler, 1993) and in turn it influences the activity of soil organisms, and thus the development of humus forms, through litter and rhizosphere effects (Emmer, 1994; Bradley and Fyles, 1996; Milleret et al., 2009).

While it is difficult to disentangle this network of multiple and often symmetrical causal relationships in the variety of situations observed in a region (Klinka et al., 1990; Kindel and Garay, 2002; Galvan et al., 2008), attempts can be made to discern a limited number of strategies by which plants, microbes and animals can adapt themselves to their physical environment, and adapt it to their own requirements (Read, 1992; Northup et al., 1998; Wardle et al., 2004), stemming in the view of humus forms as ecological attractors (Beisner et al., 2003; Ponge, 2003; Graefe and Beylich, 2006). In this respect, we suggest that multivariate methods using a wide array of sites would be better able to discern a limited array of realistic patterns than comparative studies based on a limited number of selected couples. For instance, it is current tenet that conifers impoverish the topsoil and thus change locally the humus form. However, most comparative studies on existing (non-experimental) stands (Nihlgård, 1971; Gauquelin et al., 1996; Augusto et al., 2003) are flawed by the facts (not controlled by the sampling procedure) that (i) the replacement of a deciduous by a coniferous species is often (although not always) dictated by poor growth of the previous crop, due to low soil fertility or water availability, unfavourable aspect or bad management practices, (ii) the growth rate of timber species and the duration of stand rotation (much shorter for conifers, but decided by the forester) influence the balance between aboveground nutrient immobilisation and below ground nutrient recycling through litter decomposition and mineral weathering (Schlesinger, 1977; Vitousek, 1984; Ulrich, 1987).

Studies on well-designed experimental plantations with homogeneous initial conditions conclude to an influence of tree species composition on humus form and litter decomposition (Ovington, 1954; Chapman et al., 1988), while studies on the same tree or litter species in a variety of soil and climate 
conditions conclude to a strong influence of abiotic factors (Vitousek et al., 1994; Coûteaux et al., 2002; Titeux and Delvaux, 2009). But what when both biotic and non-biotic factors vary together?

We aimed here at investigating the respective influence of abiotic conditions and tree forest species on the spatial variability of humus forms at the scale of the French continental territory. The use of a large array of forest sites of varying tree composition (including coniferous and deciduous species), soil type, climate, and parent material may help to reveal distal factors acting on humus forms, making realistic predictions possible despite of the ground noise to be expected from the variety of ecological conditions thus analysed in the same data matrix (Bednorz et al., 2000). We used 3441 plots from the phytoecological database EcoPlant (Gégout et al., 2005), covering the whole forested French territory, to investigate relationships between humus forms and environmental conditions. Plots were characterized by:

- Humus form

- Composition of the forest canopy

- Soil type

- Geological substrate

- Climate (rainfall and temperature indices)

- Geography (latitude and longitude, phytoecological region)

Data about soil chemical and physical analyses were discarded, being too fragmentary in the database and thought redundant with soil type and geological substrate (Chaplot et al., 2003). In order to better relate variations of humus forms to environmental factors, we used a Humus Index as a mean to transform the qualitative assessment of humus forms, based on a typology of morphological diagnostic characters (Green et al., 1993; Brêthes et al., 1995), into a numerical scale easier to be treated statistically (Ponge et al., 2002; Ponge and Chevalier, 2006; Lalanne et al., 2008). We used total (Van den Wollenberg, 1977; Kenkel, 2006) and partial redundancy analysis (Borcard et al., 1992; Ter Braak and Wiertz, 1994) to measure the respective contribution to humus form variation of tree canopy composition vs environmental data. Our hypothesis was that the correlation between aboveground 
vegetation and topsoil properties, which has been often described at local scales (Emmer, 1994; Ponge et al., 1997; Kounda-Kiki et al., 2006) does not hold at a more regional or even continental scale, where the influence of long-lasting distal factors such as geology and climate prevail over that of short-duration proximal factors such as forest stand composition (Augusto et al., 2003; Sadaka and Ponge, 2003; Zhang et al., 2008), while both factors combine in a nested manner (Coûteaux et al., 1995; Bernier, 1996; Aerts, 1997). Consequences of present-day anthropogenic global changes (Walther et al., 2005; Vetter et al., 2005; Rosenzweig et al., 2008) for protracted trends in the evolution of humus forms will be discussed to the light of present results and existing knowledge.

\section{Material and methods}

\subsection{Data matrix}

The complete data matrix crossed 3441 rows (sites) and 148 columns (variables). Sites were adult forest stands distributed over the whole French continental territory, with a sampling density roughly representing the distribution of forested areas (Fig. 1). No attempt was made to compensate for the over- or under-representation of some regions, given that plots were near always located several kilometres apart, thereby alleviating the risk of autocorrelation for humus profiles (Aubert et al., 2006).

Humus forms were classified in nine types according to the French classification system (Brêthes et al., 1995; Jabiol et al., 2007), which allowed the calculation of the Humus Index or HI (Ponge et al., 2002) according to the following scale of decreasing incorporation of organic matter to the mineral soil, ranging from 1 to 8 :

1. Eumull (crumby A horizon, OL horizon absent, $\mathrm{OF}$ horizon absent, $\mathrm{OH}$ horizon absent)

2. Mesomull (crumby A horizon, OL horizon present, OF horizon absent, $\mathrm{OH}$ horizon absent)

3. Oligomull (crumby A horizon, OL horizon present, $\mathrm{OF}$ horizon $<1 \mathrm{~cm}, \mathrm{OH}$ horizon absent)

4. Dysmull (crumby A horizon, OL horizon present, OF horizon $\geq 1 \mathrm{~cm}, \mathrm{OH}$ horizon absent) 
5. Amphimull (crumby A horizon, OL horizon present, OF horizon present, $\mathrm{OH}$ horizon present) and Hemimoder (compact A horizon, OL horizon present, OF horizon present, $\mathrm{OH}$ horizon absent): these humus forms are quite different in their diagnostic A horizon but both exhibit intermediate characters between dysmull and eumoder, hence same HI value)

6. Eumoder (compact A horizon, OL horizon present, $\mathrm{OF}$ horizon present, $\mathrm{OH}$ horizon $\leq 1 \mathrm{~cm}$ )

7. Dysmoder (compact A horizon, $\mathrm{OL}$ horizon present, $\mathrm{OF}$ horizon present, $\mathrm{OH}$ horizon $>1 \mathrm{~cm}$ )

8. Mor (no A horizon, OL horizon present, OF horizon present but with few animal faeces)

In the following text amphimull will be referred to amphi according to Graefe and Beylich (2006), Graefe (2007), Galvan et al. (2008) and Zanella et al. (2009). Humus forms were coded as dummy variables (taking the value 1 or 0 according to presence or absence in a given site of the corresponding humus form). Clearly, the assignment of humus forms to the system of 9 humus forms used for the calculation of HI, was sometimes imperfect. Depending on the time at which data were collected, some older classification systems were used by field collectors. In a few instances, the distinction between hemimoder, dysmull and amphimull, which is based on the presence/absence of an $\mathrm{OH}$ horizon and on the structure of the A horizon (Brêthes et al., 1995), could not be done because these forms were confused under the old-fashioned name mull-moder. In these cases, they were arbitrarily assigned to dysmull. In most cases field collectors have been trained to the recognition of diagnostic biological processes (fragmentation of litter, deposition of animal faeces, mixing of mineral with organic matter) by using the field identification booklet by Jabiol et al. (2007).

The composition of forest canopies was described by 88 variables (Appendix) measuring the percent cover of tree species according to a scale from 0 to 6 . The environment (geography, climate, geology, soil type) was described by 36 variables (Table 1) to which were added 11 geographical regions, thus totalling 47 variables, 38 of them being dummy variables. Table 1 summarizes the main characteristics of the 11 regions covering the whole continental French territory.

A soil profile was dug under a clump of adult trees with a near complete canopy cover $(\geq$ $80 \%$ at more than $2 \mathrm{~m}$ from the nearest trunk. Soil types were classified according to the last version 
154 of the French Référentiel Pédologique (AFES, 2009) and main correspondences with WRB

155 classification (IUSS, 2006) are given in Table 1.

Data were analysed by RDA (Redundancy Analysis). A total RDA was performed, using both environmental and floristic variables as independent variables $(n=171)$ and variables describing humus forms (9 dummy variables) and the Humus Index (discrete variable) as dependent variables. All variables were centred and reduced $($ mean $=0$, variance $=1)$ prior to analysis. Partial RDAs were performed using either floristic or environmental variables as co-variables in order to estimate their respective influence on humus forms (and their interaction) and to decompose the total variance according to Borcard et al. (1992). Some particular trends depicted by RDA were verified by classical statistics such as t- and $\chi^{2}$-tests and simple linear regression. All statistical treatments were performed with XLSTAT ${ }^{\circledR}$ (Addinsoft, Paris, France) under EXCEL $7^{\circledR}$ (Microsoft Corporation, Redmond, WA).

\section{Results}

The first three axes of RDA (F1, F2 and F3) extracted $83 \%$ of the explained variance (60\% for $\mathrm{F} 1,15 \%$ for $\mathrm{F} 2$ and $8 \%$ for $\mathrm{F} 3$ ). The variance explained by floristic and environmental data represented $21 \%$ of the total variance, but permutation tests (500 permutations of rows and columns) showed that the explanatory value of independent variables was highly significant $(\mathrm{p}<0.0001)$. The projection of humus variables in the plane of the first and third canonical axes (Fig. 2) showed that humus forms were distributed along F1 from most active (mull) to less active (moder, mor) forms. Humus forms belonging to the mull group (eumull, mesomull, oligomull, dysmull) were discriminated in the order of increasing accumulated organic matter while those of the moder-mor group (eumoder, dysmoder, mor) were imperfectly discriminated, pointing to other factors than geology, pedology, 
dysmull along F1, both humus forms occupying an intermediate position. The position far from the origin of the Humus Index indicated a good correlation of this numerical variable with the first canonical axis, which was verified by regression analysis (Fig. 3): the Humus Index explained by itself $57 \%$ of the variance of F1. Amphi, which occupied an intermediate position along F1, like hemimoder and dysmull, was fully discriminated by the third canonical axis, pointing to a distinct factor explaining this humus form. The second canonical axis did not correspond to any interpretable factor, the parabolic arrangement of sites in the F1-F2 plane (not shown) suggesting a horseshoe (Guttman) effect.

The projection of independent variables in the F1-F3 plane (Fig. 4) showed that points corresponding to tree species were projected near the origin while most environmental variables were projected far from the origin, more especially along F1. Tree canopies had a feeble explanatory value for humus forms, compared with environmental variables, to the exception of Abies alba Mill. for amphi. Most prominent relationships with the humus form were displayed by geology: 'alkaline' and 'acid' geological substrates were projected far from the origin on opposite sides of F1 (on 'mull' and 'mor-moder' sides, respectively), while the 'neutral' substrate was projected in an intermediate position, i.e. not far from the origin. Soil types scaled accordingly along F1, from calcisols (hypereutric cambisols) and calcosols (calcaric cambisols) on the 'mull' side to alocrisols (hyperdystric cambisols) and podzosols (podzols) on the 'mor-moder' side. This might suggest a gradient of soil acidity and nutrient availability along F1, but climatic and geographical variables scaled also along the same canonical axis, in particular 'July temperature' and 'Northern continental plains', suggesting that mull (in particular eumull) was associated with milder climate, too, without any discrimination between the respective influences of geology and temperature. This was verified by studying the distribution of humus forms and of the Humus Index according to geological substrates (Fig. 5a) and temperatures of the warmest month (Fig. 5b). The distribution of humus forms, and accordingly the value of the Humus Index (H.I.), changed significantly between 'alkaline' and 'neutral' substrates (H.I. $=2.3$ and 4.1, respectively), while they did not differ between 'neutral' and 'acid' substrates (H.I. $=4.1$ and 4.3, respectively), which were thus equivalent for the distribution of 
humus forms but not for other environmental variables, as suggested by F1 scores of environmental variables (Fig. 4).

Among climate variables, July temperature, and to a lesser extent mean annual temperature, were projected on the 'mull' side while annual rainfall and Thornthwaite Aridity Index (which increases with rainfall) were projected on the 'mor-moder' side of F1, indicating a combined influence of temperature and precipitation on humus forms, temperature having a prevailing influence as indicated by respective F1 scores. The influence of climate was verified by comparing the distribution of humus forms and the value of the Humus Index in three groups differing by July temperature $\left(>19^{\circ} \mathrm{C}, 15-19^{\circ} \mathrm{C}\right.$ and $\left.<15^{\circ} \mathrm{C}\right)$ : all differences were significant, indicating that there is a continuous gradient of decreasing presence of mull and increasing presence of mor and moder and a higher Humus Index when the environment becomes colder (Fig. 5b).

The poor influence of tree canopy on humus forms (at the scale of the whole French territory) was verified by classifying the sites in deciduous and coniferous forests (Fig. 5c): differences in the distribution of humus forms between these two groups of contrasted canopy composition were only marginally significant $(\mathrm{P}=0.05)$ and their Humus Index did not differ. Mixed forests were not taken into account, being too weakly represented in the EcoPlant database (5\%).

The third canonical axis F3 showed that 'amphi' was mostly associated with high mountain environments of the Alps and Pyrenees and to a lesser extent to Mediterranean and Aquitaine basins, and with poorly developed soils such as organosols (folic umbrisols), dolomitisols (dolomitic cambisols), peyrosols (episkeletic soils), lithosols (leptosols) and arenosols (in decreasing order of association with amphi according to F3 scores). The position of the variable 'altitude' on both positive sides of F1 and F3 (Fig. 4) indicated that higher elevation favours either 'amphi' or 'mor-moder' according to the geological substrate being 'alkaline' or 'acid', respectively (as shown by the respective projection of these two variables on F3). The projection of the variable 'latitude' on the negative side of F3 (i.e. opposed to 'amphi') can be explained by the southern localisation of high altitude and Mediterranean sites across the French territory. The respective position of 'amphi' and 
'hemimoder' along F3 also showed that they differed according to ecological factors, although being given the same Humus Index value (5).

Partial RDA showed that tree species composition and abiotic variables did not contribute to the same extent to the distribution of humus forms. When the composition of tree canopy was kept constant, environmental variables explained a significant part (19\%) of humus form variation (MonteCarlo permutation test, Pseudo-F $=0.23, \mathrm{P}<0.0001$ ), while when only tree species variables were allowed to vary, a much lower(3\%) and insignificant part of humus form variation was explained (Pseudo-F $=0.03, \mathrm{P}=1)$. The interaction between environment and tree species composition was negligible $(0.2 \%)$. Residual (unexplained) variation amounted to $79 \%$.

\section{Discussion}

We showed that at the scale of the French continental territory $(1000 \mathrm{~km}$ from West to East and $1000 \mathrm{~km}$ from North to South, elevation from 1 to $2500 \mathrm{~m}$ ) the distribution of humus forms and the value of the Humus Index were but poorly explained by the composition of the forest canopy, but were affected by geology, climate and associated soil types. This contradicts current tenets about the detrimental influence of coniferous litter on soil biological activity, which has been always demonstrated at a scale at which geology and climate could not vary and interfere with it. Our results point to a decisive influence of large-scale factors such as parent rock, temperature and to a lesser extent rainfall. We are more cautious about the influence of soil conditions on humus forms, shown by the distribution of soil types along the first canonical axis of RDA, given that the development of the soil profile is strongly influenced by soil biology (Bullinger-Weber et al., 2007; Frey et al., 2010), pointing to symmetric influences during the common development of humus forms and soils (Van Breemen, 1993; Ponge, 2003).

The influence of parent rocks on the development of humus forms may be at least partly explained by biogeochemical cycles: the nature of the subsoil influences (1) the quality of litter, in particular its mineral content (Ponge et al., 1997, 1999), and (2) the access of soil-dwelling animals to 
nutrients through their direct use of mineral matter (Bernier, 1998). Earthworms, when digging the soil, ingest mineral particles and may contribute to mineral weathering (Carpenter et al., 2007), quite to the same extent as plant roots and their symbionts (Van Breemen et al., 2000). In the sandy context of the Fontainebleau forest, it has been shown that the presence of a limestone table, at a depth not exceeding that available to beech roots, allowed the maintenance of an active mull-forming earthworm population through a litter enriched in calcium (Ponge et al., 1999). Other studies showed that earthworms were able to modify mineral assemblages, thereby increasing the available nutrient pool of the topsoil (Rangel et al., 1999).

The influence of climate (mull associated with more heat) can be understood through the stimulatory influence of temperature on most chemical processes, in particular those involved in organic matter decomposition (Aerts, 1997) and mineral weathering (Turner et al., 2010; Williams et al., 2010). In addition to benefits of heat for their own activity of cold-blooded animals (Briones et al., 2010), mull-forming invertebrates may benefit from the more rapid recycling of elements authorized by an increase in temperature (Zhang et al., 2008), at least in the absence of any limitation by drought (Cortez, 1998) which is often marginal in OF and OH horizons. The association of mor and moder with heavy rainfall can be explained by (1) the intensity of leaching, which favours nutrient losses and thus topsoil impoverishment (Turner et al., 2010), and (2) the association of heavy rainfall with altitude and low temperatures (Roe, 2005).

The poor influence of tree species on humus forms, compared to that of geology and climate, can be explained by the influence of parent material and climate on litter quality. For a given tree species, the composition of leaf or needle foliage may vary according to substrate (Nicolai, 1988; Hättenschwiler et al., 2003) and to a lesser extent according to climate (Aerts, 1997), making palatability and nutritional quality of tree litter more dependent on the environmental context than on the taxonomic level. Bernier (1998) showed that the anecic earthworm Lumbricus terrestris L. consumed spruce needles from a coniferous selection forest (not planted) and mixed them with the mineral soil, stemming in the building of mull humus. Such results point on possible confusion of negative coniferous effects with the detrimental influence of (1) plantation forests (whether deciduous 
or not) to which local animal and microbial communities needs time to become, if any, adapted (Hansen, 1999), and (2) associated ground vegetation (Wolters, 1999). In the present database most measurement plots were installed in indigenous forest stands, avoiding young plantations. However, it must be noticed that we found a marginally significant negative correlation between the Humus Index and the species richness of the tree canopy $(r=-0.035, P=0.041)$, which could be explained by either or both (1) the favourable effect of tree mixture on litter decomposition and (Chapman et al., 1988; Aubert et al., 2006; but see Wardle et al., 2003), and (2) distal effects of environmental factors on both humus forms and plant diversity (Ponge, 2003; Wardle et al., 2004). A much better negative correlation (the higher the Humus Index the lower the species richness) was observed with ground flora but this relationship held true at the local scale only (Lalanne et al., 2010).

The fact that moder (eumoder and dysmoder) and mor could not be discriminated by the first canonical axis of RDA points to the existence of other possible environmental influences, not taken into account in our data matrix, such as soil chemistry, known to discriminate moder and mor in addition to morphological and biological characters (Wilson et al., 2001). In addition, it must be pointed out that in the French context the mor humus form is rare and never typical.

The particular case of amphi is worth to notice. This humus form, which has been previously confused with dysmull, hemimoder or moder (Brêthes et al., 1995), is associated with highly seasonal mull-forming activity in an otherwise favourable geological context (Tagger et al., 2008; Galvan et al., 2008): the shorter the season during which invertebrate (and microbial) activity is possible, the thicker will be the organic horizon (of moder type) overlying a crumby A horizon (of mull type). This may happen both at higher elevation and in Mediterranean landscapes when the richness of the substrate (limestone, dolomitic rocks) allows the activity of subterranean animals during less favourable seasons. Although still badly understood and imperfectly described, amphi does not seem in line with the temperature/acidity gradient corresponding to the contrast between mull and mor.

A large part of the variation of humus forms was not explained by the abovementioned factors. The bulk of unexplained variation (79\%) could be ascribed to local factors, the influence of 
311 which has been demonstrated in particular cases (detailed in the Introduction), such as ground

312 vegetation, previous land use, management options, canopy density, and the mosaic patchwork of

313 animal and microbial populations. Nonetheless, the fact that geology and climate may explain by

314 themselves a fifth of the total variation of this highly fluctuating compartment of the forest ecosystem

315 may help to discern possible trends in the actual context of global warming. Linear regression analysis

$316(\mathrm{~F}=182, \mathrm{P}<0.0001)$ showed that the Humus Index (H.I.) was related to July temperature $(\mathrm{J})$ according

317 to the following equation:

318 H.I. $=9-0.3 \mathrm{~J}$

319 According to this linear relationship any increase of $1^{\circ} \mathrm{C}$ would correspond to a decrease of the Humus

320 Index averaging 0.3 units. This is highly speculative, given what we know about the counteracting

321 influences of litter recalcitrance due to fertilisation with $\mathrm{CO}_{2}$ (Cotrufo and Ineson, 1996; but see

322 Coûteaux et al., 1999) and anthropogenic acidification and eutrophication (Thimonier et al., 1994).

323 Nonetheless, in the present state of our knowledge, we can hypothesize in accordance with Graefe

324 (2007) that the combined influence of increased litter recalcitrance and acidification (favouring the

325 accumulation of litter) and warming trends and eutrophication (favouring the activity of soil

326 organisms) will extend the domain of amphi, a humus form not fitted with the mull-mor gradient of

327 decreasing litter quality and biological activity associated with climate/trophic constraints (Ponge, 328 2003).

\section{Acknowledgements}

331 EcoPlant is a phytoecological database financially supported by the Paris Institute of Technology for

332 Life, Food, and Environmental Science (AgroParisTech), the Environment and Energy Management

333 Agency (ADEME), and the National Office of Forests (ONF) which are greatly acknowledged. 
Aerts, R., 1997. Climate, leaf litter chemistry and leaf litter decomposition in terrestrial ecosystems: a triangular relationship. Oikos 79, 439-449.

AFES, 2009. Référentiel Pédologique 2008, coordinated by D. Baize and C.M. Girard. Quae, Paris, France.

Arp, P.A., Krause, H.H., 1984. The forest floor: lateral variability as revealed by systematic sampling. Can. J. Soil Sci. 64, 423-437.

Aubert, M., Bureau, F., Alard, D., Bardat, J., 2004. Effect of tree mixture on the humic epipedon and vegetation diversity in managed beech forests (Normandy, France). Can. J. For. Res. 34, 233 248.

Aubert, M., Margerie, P., Ernoult, A., Decaëns, T., Bureau, F., 2006. Variability and heterogeneity of humus forms at stand level: comparison between pure beech and mixed beech-hornbeam forest. Ann. For. Sci. 63, 177-188.

Augusto, L., Dupouey, J.L., Ranger, J., 2003. Effects of tree species on understory vegetation and environmental conditions in temperate forests. Ann. For. Sci. 60, 823-831.

Bednorz, F., Reichstein, M., Broll, G., Holtmeier, F.K., Urfer, W., 2000. Humus forms in the forestalpine tundra ecotone at Stillberg (Dischmatal, Switzerland: spatial heterogeneity and classification. Arct. Antarct. Alp. Res. 32, 21-29.

Beisner, B.E., Haydon, D.T., Cuddington, K., 2003. Alternative stable states in ecology. Front. Ecol. Environ. 1, 376-382.

Bernier, N., 1996. Altitudinal changes in humus form dynamics in a spruce forest at the montane level. Plant Soil 178, 1-28.

Bernier, N., 1998. Earthworm feeding activity and development of the humus profile. Biol. Fertil. Soils 26, 215-223. 
Bernier, N., Ponge, J.F., 1994. Humus form dynamics during the sylvogenetic cycle in a mountain spruce forest. Soil Biol. Biochem. 26, 183-220.

Bernier, N., Ponge, J.F., André, J., 1993. Comparative study of soil organic layers in two bilberryspruce forest stands (Vaccinio-Piceetea): relation to forest dynamics. Geoderma 59, 89-108.

Boettcher, S.E., Kalisz, P.J., 1990. Single-tree influence on soil properties in the mountains of eastern Kentucky. Ecology 71, 1365-1372.

Borcard, D., Legendre, P., Drapeau, P., 1992. Partialling out the spatial component of ecological variation. Ecology 73, 1045-1055.

Bradley, R.L., Fyles, J.W., 1996. Interactions between tree seedling roots and humus forms in the control of soil C and N cycling. Biol. Fertil. Soils 23, 70-79.

Brêthes, A., Brun, J.J., Jabiol, B., Ponge, J.F., Toutain, F., 1995. Classification of forest humus forms: a French proposal. Ann. Sci. For. 52, 535-546.

Briones, M.J.I., Garnett, M.H., Inseon, P., 2010. Soil biology and warming play a key role in the release of 'old C' from organic soils. Soil Biol. Biochem. 42, 960-967.

Bullinger-Weber, G., Le Bayon, R.C., Guenat, C., Gobat, J.M., 2007. Influence of some physicochemical and biological parameters on soil structure formation in alluvial soils. Eur; J. Soil Biol. 43, 57-70.

Burghouts, T.B.A., Van Straalen, N.M., Bruijnzeel, L.A., 1998. Spatial heterogeneity of element and litter turnover in a Bornean rain forest. J. Trop. Ecol. 14, 477-506.

Carpenter, D., Hodson, M.E., Eggleton, P., Kirk, C., 2007. Earthworm induced mineral weathering: preliminary results. Eur. J. Soil Biol. 43, S176-S183.

Chaplot, V., Van Vliet-Lanoë, B., Walter, C., Curmi, P., Cooper, M., 2003. Soil spatial distribution in the Armorican massif, western France: effect of soil-forming factors. Soil Sci. 168, 856-868. 
Chapman, K., Whittaker, J.B., Heal, O.W., 1988. Metabolic and faunal activity in litters of tree mixtures compared with pure stands. Agric. Ecosyst. Environ. 24, 33-40.

Chauvat, M., Ponge, J.F., Wolters, V., 2007. Humus structure during a spruce forest rotation: quantitative changes and relationship to soil biota. Eur. J. Soil Sci. 58, 625-631.

Cortez, J., 1998. Field decomposition of leaf litters: relationships between decomposition rates and soil moisture, soil temperature and earthworm activity. Soil Biol. Biochem. 30, 783-793.

Cotrufo, M.F., Ineson, P., 1996. Elevated $\mathrm{CO}_{2}$ reduces field decomposition rates of Betula pendula (Roth.) leaf litter. Oecologia 106, 525-530.

Coûteaux, M.M., Bottner, P., Berg, B., 1995. Litter decomposition, climate and litter quality. Trends Ecol. Evol. 10, 63-66.

Coûteaux, M.M., Kurz, C., Bottner, P., Raschi, A., 1999. Influence of increased atmospheric $\mathrm{CO}_{2}$ concentration on quality of plant material and litter decomposition. Tree Physiol. 19, 301-311.

Coûteaux, M.M., Sarmiento, L., Bottner, P., Acevedo, D., Thiéry, J.M., 2002. Decomposition of standard plant material along an altitudinal transect (65-3968 m) in the tropical Andes. Soil Biol. Biochem. 34, 69-78.

Crocker, R.L., Major, J., 1955. Soil development in relation to vegetation and surface age at Glacier Bay, Alaska. J. Ecol. 43, 427-448.

Daniel, T.W., Schmidt, J., 1972. Lethal and nonlethal effects of the organic horizons of forested soils on the germination of seeds from several associated conifer species of the Rocky Mountains. Can. J. For. Res. 2, 179-184.

Davies, R.I., Coulson, C.B., Lewis, D.A., 1964. Polyphenols in plant, humus, and soil. IV. Factors leading to increase in biosynthesis of polyphenols in leaves and their relationship to mull and mor formation. J. Soil Sci. 15, 310-318. 
Dupouey, J.L., Dambrine, E., Laffite, J.D., Moares, C., 2002. Irreversible impact of past land use on forest soils and biodiversity. Ecology 83, 2978-2984.

Dwyer, L.M., Merriam, G., 1981. Infleunce of topographic heterogeneity on deciduous litter decomposition. Oikos 37, 228-237.

Emmer, I.M., 1994. Humus form characteristics in relation to undergrowth vegetation in a Pinus sylvestris forest. Acta Oecol. 15, 677-687.

Emmer, I.M., Sevink, J., 1994. Temporal and vertical changes in the humus form profile during a primary succession of Pinus sylvestris. Plant Soil 167, 281-295.

Falkengren-Grerup, U., Tyler, G., 1993. Soil chemical properties excluding field-layer species from beech forest mor. Plant Soil 148, 185-191.

Frey, B., Rieder, S.R., Brunner, I., Plötze, M., Koetzsch, S., Lapanje, A., Brandl, H., Furrer, G., 2010. Weathering-associated bacteria from the Damma glacier forefield: physiological capabilities and impact on granite dissolution. Appl. Environ. Microbiol. 76, 4788-4796.

Galvan, P., Ponge, J.F., Chersich, S., Zanella, A., 2008. Humus components and soil biogenic structures in Norway spruce ecosystems. Soil Sci. Soc. Am. J. 72, 548-557.

Gauquelin, T., Gers, C., Deharveng, L., 1996. Physico-chemical heterogeneity of superficial soil layers in conifer plantations versus original broad leaf forests in Ariege (Pyrenees, France). Commun. Soil Sci. Plant. Anal. 27, 2361-2380.

Gégout, J.C., Coudun, C., Bailly, G., Jabiol, B., 2005. EcoPlant : a forest site database linking floristic data with soil and climate variables. J. Veg. Sci. 16, 257-260.

Godefroid, S., Massant, W., Koedam, N., 2005. Variation in the herb species response and the humus quality across a 200-year chronosequence of beech and oak plantations in Belgium. Ecography $28,223-235$. 
Goldberg, D.E., 1982. The distribution of evergreen and deciduous trees relative to soil type: an example from the Sierra Madre, Mexico, and a general model. Ecology 63, 942-951.

Gourbière, F., 1983. Pourriture blanche de la litière d'Abies alba Mill. II. Répartition spatiotemporelle et activité annuelle des Basidiomycètes du genre Collybia. Rev. Ecol. Biol. Sol 20, 461-474.

Graefe, U., 2007. Gibt es in Deutschland die Humusform Amphi? Mitt. Dtsch. Bodenk. Ges. 110, 459460.

Graefe, U., Beylich, A., 2006. Humus forms as tool for upscaling soil biodiversity data to landscape level? Mitt. Dtsch. Bodenk. Ges. 108, 6-7.

Green, R.N., Trowbridge, R.L., Klinka, K., 1993. Towards a taxonomic classification of humus forms. For. Sci. Monogr. 29, 1-49.

Hansen, R.A., 1999. Red oak litter promotes a microarthropod functional group that accelerates its decomposition. Plant Soil 209, 37-45.

Hättenschwiler, S., Hagerman, A.E., Vitousek, P.M., 2003. Polyphenols in litter from tropical montane forests across a wide range in soil fertility. Biogeochemistry 64, 129-148.

Hölscher, D., Schade, E., Leuschener, C., 2001. Effects of coppicing in temperate deciduous forests on ecosystem nutrient pools and soil fertility. Basic Appl. Ecol. 2, 155-164.

Hoogerkamp, M., Rogaar, H., Eijsackers, H.J.P., 1983. Effect of earthworms on grassland on recently reclaimed polder soils in the Netherlands. In: Satchell, J.E. (Ed.), Earthworm Ecology: from Darwin to Vermiculture. Chapman and Hall, London, pp. 85-105.

IUSS, 2006. IUSS Working Group World Reference Base for Soil Resources 2006. FAO, Rome, Italy.

Jabiol, B., Brêthes, A., Ponge, J.F., Toutain, F., Brun, J.J., 2007. L’Humus sous toutes ses Formes, seconde édition. AgroParisTech-ENGREF, Nancy. 
Kenkel, N.C., 2006. On selecting an appropriate multivariate analysis. Can. J. Plant Sci. 86, 663-676.

Kindel, A., Garay, I., 2002. Humus form in ecosystems of the Atlantic Forest, Brazil. Geoderma 108, $101-118$.

Klinka, K., Wang, Q., Carter, R.E., 1990. Relationships among humus forms, forest floor nutrient properties, and understory vegetation. For. Sci. 36, 564-581.

Koerner, W., Dupouey, J.L., Dambrine, E., Benoît, M., 1997. Influence of past land use on the vegetation and soils of present day forest in the Vosges mountains, France. J. Ecol. 85, 351358.

Kounda-Kiki, C., Vaçulik, A., Ponge, J.F., Sarthou, C., 2006. Humus profiles under main vegetation types in a rock savanna (Nouragues inselberg, French Guiana). Geoderma 136, 819-829.

Kuuluvainen, T., Hokkannen, T.J., Järvinen, E., Pukkala, T., 1993. Factors related to seedling growth in a boreal Scots pine stand: a spatila analysis of a vegetation-soil system. Can. F. For. Res. 23, 2101-2109.

Kuuluvainen, T., Hokkannen, T.J., Pukkala, T., Järvinen, E., 1994. A zone-of-influence model to predict the effect of trees on the spatial distribution of understorey vegetation and soil properties in a boreal Scots pine stand. In: Rennolls, K. (Ed.), Stochastic Spatial Models in Forestry. The University of Greenwich, London, pp. 143-152.

Lalanne, A., Bardat, J., Lalanne-Amara, F., Gautrot, T., Ponge, J.F., 2008. Opposite responses of vascular plant and moss communities to changes in humus form, as expressed by the Humus Index. J. Veg. Sci. 19, 645-652.

Lalanne, A., Bardat, J., Lalanne-Amara, F., Ponge, J.F., 2010. Local and regional trends in the ground vegetation of beech forests. Flora 205, 484-498. 
Leuschner, C., Rode, M.W., Danner, E., Lübbe, K., Clauß, C., Margraf, M., Runge, M., 1993. Soil profile alteration and humus accumulation during heathland-forest succession in NW Germany. Scripta Geobot. 21, 73-84.

Loranger, G., Ponge, J.F., Imbert, D., Lavelle, P., 2002. Leaf decomposition in two semi-evergreen tropical forests: influence of litter quality. Biol. Fertil. Soils 35, 247-252.

Marland, G., Pielke Sr, R.A., Apps, M., Avissar, R., Betts, R.A., Davis, K.J., Frumhoff, P.C., Jackson, S.T., Joyce, L.A., Kauppi, P., Katzenberger, J., McDicken, K.G., Neilson, R.P., Niles, J.O., Niyogi, D.S., Norby, R.J., Pena, N., Sampson, N., Xue, Y., 2003. The climatic impacts of land surface change and carbon management, and the implications for climate-change mitigation policy. Clim. Pol. 3, 149-157.

Milleret, R., Le Bayon, R.C., Lamy, F., Gobat, J.M., Boivin, P., 2009. Impact of roots, mycorrhizas and earthworms on soil physical properties as assessed by shrinkage analysis. J. Hydrol. 373, 499-507.

Nicolai, V., 1988. Phenolic and mineral content of leaves influences decomposition in European forest ecosystems. Oecologia 75, 575-579.

Nihlgård, B., 1971. Pedological inflrunce of spruce planted on former beech forest soils in Scania, South Sweden. Oikos 22, 302-314.

Northup, R.R., Dahlgren, R.A., McColl, J.G., 1998. Polyphenols as regulators of plant-litter-soil interactions in northern California's pygmy forest: a positive feedback? Biogeochemistry 42, $189-220$.

Northup, R.R., Dahlgren, R.A., Yu, Z., 1995. Intraspecific variation of conifer phenolic concentration on a marine terrace soil acidity gradient: a new interpretation. Plant Soil 171, 255-262.

Ovington, J.D., 1954. Studies of the development of woodland conditions under different trees. II. The forest floor. J. Ecol. 42, 71-80. 
Peltier, A., Ponge, J.F., Jordana, R., Ariño, A., 2001. Humus forms in Mediterranean scrublands with Aleppo pine. Soil Sci. Soc. Am. J. 65, 884-896.

Perry, D.A., 1995. Self-organizing systems across scales. Trends Ecol. Evol. 10, 241-244.

Ponge, J.F., 2003. Humus forms in terrestrial ecosystems: a framework to biodiversity. Soil Biol. Biochem. 35, 935-945.

Ponge, J.F., André, J., Zackrisson, O., Bernier, N., Nilsson, M.C., Gallet, C., 1998. The forest regeneration puzzle: biological mechanisms in humus layer and forest vegetation dynamics. Bioscience 48, 523-530.

Ponge, J.F., Arpin, P., Sondag, F., Delecour, F., 1997. Soil fauna and site assessment in beech stands of the Belgian Ardennes. Can. J. For. Res. 27, 2053-2064.

Ponge, J.F., Chevalier, R., 2006. Humus Index as an indicator of forest stand and soil properties. For. Ecol. Manag. 233, 165-175.

Ponge, J.F., Chevalier, R., Loussot, P., 2002. Humus Index: an integrated tool for the assessment of forest floor and topsoil properties. Soil Sci. Soc. Am. J. 66, 1996-2001.

Ponge, J.F., Patzel, N., Delhaye, L., Devigne, E., Levieux, C., Beros, P., Wittebrodt, R., 1999. Interactions between earthworms, litter and trees in an old-growth beech forest. Biol. Fertil. Soils 29, 360-370.

Rangel, A.F., Madero, E., Thomas, R.J., Friesen, D.K., Decaëns, T., 1999. Ion exchange properties of casts of the anecic earthworm (Martiodrilus carimaguensis Jiménez and Moreno) in a Colombian savanna Oxisol. Pedobiologia 43, 795-801.

Read, D.J., 1992. The mycorrhizal fungal community with special reference to nutrient mobilization. In: Carroll, G.C., Wicklow, D.T. (Eds.), The Fungal Community. Dekker, New York, pp. 631652. 
Riha, S.J., James, B.R., Senesac, G.P., Pallant, E., 1986. Spatial variability of soil pH and organic matter in forest plantations. Soil Sci. Soc. Am. J. 50, 1347-1352.

Roe, G.H., 2005. Orographic precipitation. Annu. Rev. Earth Planet. Sci. 33, 645-671.

Rosenzweig, C., Karoly, D., Vicarelli, M., Neofotis, P., Wu, Q., Casassa, G., Menzel, A., Root, T.L., Estrella, N., Seguin, B., Tryjanowski, P., Liu, C., Rawlins, S., Imeson, A., 2008. Attributing physical and biological impacts to anthropogenic climate change. Nature 453, 353-358.

Sadaka, N., Ponge, J.F., 2003. Climatic effects on soil trophic networks and the resulting humus profiles in holm oak (Quercus rotundifolia) forests in the High Atlas of Morocco as revealed by correspondence analysis. Eur. J. Soil Sci. 54, 767-777.

Sagot, C., Brun, J.J., Grossi, J.L., Chauchat, J.H., Boudin, G., 1999. Earthworm distribution and humus forms in the development of a semi-natural alpine spruce forest. Eur. J. Soil Biol. 35, 163-169.

Salmon, S., Artuso, N., Frizzera, L., Zampedri, R., 2008. Relationships between soil fauna communities and humus forms: reponse to forest dynamics and solar radiation. Soil Biol. Biochem. 40, 1707-1715.

Scheu, S., Schulz, E., 1996. Secondary succession, soil formation and development of a diverse community of oribatids and saprophagous soil macro-invertebrates. Biodivers. Conserv. 5, 235-250.

Schlesinger, W.H., 1977. Carbon balance in terrestrial detritus. Ann. Rev. Ecol. Syst. 8, 51-81.

Switzer, G.L., Shelton, M.G., Nelson, L.E., 1979. Successional development of the forest floor and soil surface on upland sites of the East Gulf coastal plain. Ecology 60, 1162-1171.

Tagger, S., Périssol, C., Criquet, S., Aubert, G., Neville, P., Le Petit, J., Toutain, F., 2008. Characteization of an amphimull under Mediterranean evergreen oak forest (Quercus ilex): micromorphological and biodynamic descriptions. Can. J. For. Res. 38, 268-277. 
544 Ter Braak, C.J.F., Wiertz, J., 1994. On the statistical analysis of vegetation change: a wetland affected by water extraction and soil acidification. J. Veg. Sci. 5, 361-372.

Thimonier, A., Dupouey, J.L., Bost, F., Becker, M., 1994. Simultaneous eutrophication and acidification of a forest ecosystem in North-East France. New Phytol. 126, 533-539.

Titeux, H., Delvaux, B., 2009. Experimental study of DOC, nutrients and metals release from fores floors developed under beech (Fagus sylvatica L.) on a Cambisol and a Podzol. Geoderma $148,291-298$.

Turk, J.K., Goforth, B.R., Graham, R.C., Kendrick, K.J., 2008. Soil morphology of a debris flow chronosequence in a coniferous forest, southern California, USA. Geoderma 146, 157-165.

Turner, B.F., White, A.F., Brantley, S.L., 2010. Effects of temperature on silicate weathering: solute fluxes and chemical weathering in a temperate rain forest watershed, Jamieson Creek, British Columbia. Chem. Geol. 269, 62-78.

Ulrich, B., 1987. Stability, elasticity, and resilience of terrestrial ecosystems with respect to matter balance. In: Schulze, E.D., Zwölfer, H. (Eds.), Potentials and Limitations of Ecosystem Analysis. Ecol. Stud. 61, 11-49.

Van Breemen, N., 1993. Soils as biotic constructs favouring net productivity. Geoderma 57, 183-211.

Van Breemen, N., Lundström, U.S., Jongmans, A.G., 2000. Do plants drive podzolization via rockeating mycorrhizal fungi? Geoderma 94, 163-171.

Van Calster, H., Baeten, L., De Schrijver, A., De Keersmaeker, L., Rogister, J.E., Verheyen, K., Hermy, M., 2007. Management driven changes (1967-2005) in soil acidity and the understorey plant community following conversion of a coppice-with-standards forest. For. Ecol. Manag. 241, 258-271.

Van den Wollenberg, A.L., 1977. Redundancy analysis: an alternative for canonical correlation analysis. Psychometrika 42, 207-219. 
Vetter, M., Wirth, C., Böttcher, H., Churkina, G., Schulze, E.D., Wutzler, T., Weber, G., 2005. Partitioning direct and indirect human-induced effects on carbon sequestration of managed coniferous forests using model simulations and forest inventories. Glob. Change Biol. 11, 810827.

Vitousek, P.M., 1984. A general theory of forest nutrient dynamics. In: Ågren, G.I. (Ed.), State and Change of Forest Ecosystems: Indicators in Current Research. Swedish University of Agricultural Sciences, Department of Ecology and Environmental Research, Report no. 13, pp. 121-135.

Vitousek, P.M., Turner, D.R., Parton, W.J., Sanford, R.L., 1994. Litter decomposition on the Mauna Loa enviromental matrix, Hawai'i: patterns, mechanisms, and models. Ecology 75, 418-429.

Walther, G.R., Berger, S., Sykes, M.T., 2005. An ecological 'footprint' of climate change. Proc. R. Soc. Lond. B Biol. Sci. 272, 1427-1432.

Wardle, D.A., Bardgett, R.D., Klironomos, J.N., Setälä, H., Van der Putten, W.H., Wall, D.H., 2004. Ecological linkages between aboveground and belowground biota. Science 304, 1629-1633.

Wardle, D.A., Lavelle, P., 1997. Linkages between soil biota, plant litter quality and decomposition. In: Cadish, G., Giller, K.E. (Eds.), Driven by Nature: Plant Litter Quality and Decomposition. CAB International, Wallingford, pp. 107-124.

Wardle, D.A., Nilsson, M.C., Zackrisson, O., Gallet, C., 2003. Determinants of litter mixing effects in a Swedish boreal forest. Soil Biol. Biochem. 35, 827-835.

Wilcox, C.S., Domínguez, J., Parmelee, R.W., Mccartney, D.A., 2002. Soil carbon and nitrogen dynamics in Lumbricus terrestris L. middens in four arable, a pasture, and a forest ecosystems. Biol. Fertil. Soils 36, 26-34.

Williams, J.Z., Bandstra, J.Z., Pollard, D., Brantley, S.L., 2010. The temperature dependence of feldspar dissolution determined using a coupled weathering-climate model for Holocene-aged loess soils. Geoderma 156, 11-19. 
593 Wilson, S.McG., Pyatt, D.G., Malcolm, D.C., Connolly, T., 2001. The use of ground vegetation and 594 humus type as indicators of soil nutrient regime for an ecological site classification of British $595 \quad$ forests. For. Ecol. Manag. 140, 101-116.

596 Wironen, M., Moore, T.R., 2006. Exotic earthworm invasion increases soil carbon and nitrogen in an old-growth forest in southern Quebec. Can. J. For. Res. 36, 845-854.

598 Wolters, V., 1999. Allium ursinum litter triggering decomposition on a beech forest floor: the effect of earthworms. Pedobiologia 43, 528-536.

600 Zanella, A., Jabiol, B., Ponge, J.F., Sartori, G., De Waal (R.), Van Delft, B., Graefe, U., Cools, N., 601

602 Katzensteiner, K., Hager, H., English, M., Brêthes, A., 2009. Toward a European humus forms reference base. Stud. Trentini Sci. Nat. 85, 145-151.

603

Zhang, D., Hui, D., Luo, Y., Zhou, G., 2008. Rates of litter decomposition in terrestrial ecosystems:

604 global patterns and controlling factors. J. Plant Ecol. 1, 85-93.

605 
Figure 1. Distribution of the 3441 forest plots selected within the EcoPlant database over the French continental territory.

612 Figure 2. Total Redundancy Analysis (RDA): projection of dependent variables (9 humus forms as dummy variables and the Humus Index as discrete variable) in the F1-F3 plane of canonical axes

Figure 3. Diagram showing the linear relationship between the Humus Index and the first canonical axis (F1) of total RDA.

Figure 4. Total Redundancy Analysis (RDA): projection of independent variables (148 variables describing geology, climate, soil type, geography and woody flora) in the F1-F3 plane. Environmental variables are described in Table 1. Tree species (listed in the Appendix) were represented as black dots, given their position not far enough from the origin. A more detailed view of this zone, showing plant codes (see Appendix), was inserted for the sake of clarity.

Figure 5. Distribution of humus forms and average values of the Humus Index according to geology (a), mean July temperature (b) and forest types (c). 
Table 1. Average values of quantitative variables (geography, climate) and percent occurrence of dummy variables (geology, pedology) used in Redundance Analysis (RDA) in each geographical region covered by the study.

Geographical regions were also included as dummy variables (refer to text for further details)

\begin{tabular}{|c|c|c|c|c|c|c|c|c|c|c|c|c|}
\hline $\begin{array}{l}\text { Variable } \\
\text { name }\end{array}$ & $\begin{array}{l}\text { Meaning } \\
\end{array}$ & $\begin{array}{l}\text { Brittany } \\
(n=99)\end{array}$ & $\begin{array}{l}\text { Northern } \\
\text { continental } \\
\text { plains } \\
(\mathrm{n}=\mathbf{6 5 4})\end{array}$ & $\begin{array}{l}\text { Vosges } \\
(n=472)\end{array}$ & $\begin{array}{l}\text { Jura } \\
(\mathrm{n}=171)\end{array}$ & $\begin{array}{l}\begin{array}{l}\text { Paris } \\
\text { basin }\end{array} \\
(\mathrm{n}=971)\end{array}$ & $\begin{array}{l}\text { Massif } \\
\text { Central } \\
(n=229)\end{array}$ & $\begin{array}{l}\text { Alps } \\
(n=417)\end{array}$ & $\begin{array}{l}\text { Pyrenees } \\
(\mathrm{n}=151)\end{array}$ & $\begin{array}{l}\begin{array}{l}\text { Rhone } \\
\text { valley }\end{array} \\
(\mathrm{n}=18)\end{array}$ & $\begin{array}{l}\begin{array}{l}\text { Aquitaine } \\
\text { basin }\end{array} \\
(\mathrm{n}=247)\end{array}$ & $\begin{array}{l}\begin{array}{l}\text { Mediterranean } \\
\text { basin }\end{array} \\
(\mathrm{n}=15)\end{array}$ \\
\hline \multicolumn{13}{|l|}{ Geography: } \\
\hline Longitude & $\begin{array}{l}\text { Lambert II extended X } \\
\text { coordinates }(\mathrm{m})\end{array}$ & 281307 & 900896 & 952636 & 893364 & 614624 & 673735 & 906434 & 494659 & 821386 & 414911 & 783533 \\
\hline $\begin{array}{l}\text { Latitude } \\
\text { Climate: }\end{array}$ & $\begin{array}{l}\text { Lambert II extended Y } \\
\text { coordinates }(\mathrm{m})\end{array}$ & 2397578 & 2356856 & 2377920 & 2227127 & 2359891 & 2044778 & 2067732 & 1771497 & 2053854 & 1907341 & 1876533 \\
\hline $\begin{array}{l}\text { Mean } \\
\text { temperature }\end{array}$ & Mean annual temperature & $11^{\circ} \mathrm{C}$ & $10^{\circ} \mathrm{C}$ & $8^{\circ} \mathrm{C}$ & $9^{\circ} \mathrm{C}$ & $10^{\circ} \mathrm{C}$ & $9^{\circ} \mathrm{C}$ & $7^{\circ} \mathrm{C}$ & $10^{\circ} \mathrm{C}$ & $11^{\circ} \mathrm{C}$ & $12^{\circ} \mathrm{C}$ & $13^{\circ} \mathrm{C}$ \\
\hline $\begin{array}{l}\text { January } \\
\text { temperature }\end{array}$ & Mean January temperature & $5^{\circ} \mathrm{C}$ & $1^{\circ} \mathrm{C}$ & $-0.2^{\circ} \mathrm{C}$ & $0.4^{\circ} \mathrm{C}$ & $3^{\circ} \mathrm{C}$ & $1.5^{\circ} \mathrm{C}$ & $-1.3^{\circ} \mathrm{C}$ & $4^{\circ} \mathrm{C}$ & $2.4^{\circ} \mathrm{C}$ & $6^{\circ} \mathrm{C}$ & $5^{\circ} \mathrm{C}$ \\
\hline $\begin{array}{l}\text { July } \\
\text { temperature }\end{array}$ & Mean July temperature & $17^{\circ} \mathrm{C}$ & $19^{\circ} \mathrm{C}$ & ${ }^{17^{\circ} \mathrm{C}}$ & $18^{\circ} \mathrm{C}$ & $18^{\circ} \mathrm{C}$ & $17^{\circ} \mathrm{C}$ & $16^{\circ} \mathrm{C}$ & $18^{\circ} \mathrm{C}$ & $21^{\circ} \mathrm{C}$ & $20^{\circ} \mathrm{C}$ & $22^{\circ} \mathrm{C}$ \\
\hline Altitude & Elevation $(\mathrm{m})$ & 96 & 252 & 617 & 596 & 161 & 743 & 1277 & 834 & 290 & 157 & 280 \\
\hline Rainfall & Mean annual rainfall $(\mathrm{mm})$ & 894 & 854 & 1279 & 1307 & 744 & 1202 & 1386 & 1101 & 938 & 969 & 855 \\
\hline Water balance & $\begin{array}{l}\text { Rainfall:potential } \\
\text { evaporation (May to } \\
\text { September) Thornthwaite } \\
\text { index }\end{array}$ & -175 & -124 & 28 & 69 & -183 & -30 & 122 & -39 & -119 & -154 & -251 \\
\hline Aridity index & $\begin{array}{l}\text { Rainfall:temperature } \\
\text { Martonne index }\end{array}$ & 43 & 43 & 71 & 70 & 37 & 65 & 84 & 55 & 44 & 43 & 38 \\
\hline \multicolumn{13}{|l|}{ Parent rock: } \\
\hline Acid & Acid silicate rocks & $52 \%$ & $41 \%$ & $91 \%$ & $9 \%$ & $66 \%$ & $74 \%$ & $30 \%$ & $57 \%$ & $39 \%$ & $73 \%$ & $13 \%$ \\
\hline Neutral & $\begin{array}{l}\text { Weakly acidic silicate } \\
\text { rocks }\end{array}$ & $46 \%$ & $0 \%$ & $6 \%$ & $0 \%$ & $2 \%$ & $19 \%$ & $5 \%$ & $8 \%$ & $0 \%$ & $0 \%$ & $0 \%$ \\
\hline Alkaline & Calcareous rocks & $2 \%$ & $59 \%$ & $3 \%$ & $91 \%$ & $31 \%$ & $4 \%$ & $65 \%$ & $35 \%$ & $61 \%$ & $26 \%$ & $87 \%$ \\
\hline $\begin{array}{l}\text { Soil type } \\
\text { (AFES): }\end{array}$ & Soil type (WRB): & & & & & & & & & & & \\
\hline Alocrisol & Cambisol (Hyperdystric) & $37 \%$ & $7 \%$ & $27 \%$ & $4 \%$ & $8 \%$ & $31 \%$ & $14 \%$ & $12 \%$ & $0 \%$ & $12 \%$ & $0 \%$ \\
\hline Andosol & Andosol & $0 \%$ & $0.0 \%$ & $0 \%$ & $0 \%$ & $0 \%$ & $0.4 \%$ & $0 \%$ & $0 \%$ & $0 \%$ & $0 \%$ & $0 \%$ \\
\hline Arenosol & Arenosol & $1 \%$ & $1 \%$ & $0 \%$ & $0 \%$ & $0.1 \%$ & $0 \%$ & $0 \%$ & $0 \%$ & $0 \%$ & $6 \%$ & $0 \%$ \\
\hline Brunisol & Cambisol & $19 \%$ & $21 \%$ & $36 \%$ & $25 \%$ & $17 \%$ & $31 \%$ & $23 \%$ & $31 \%$ & $17 \%$ & $21 \%$ & $7 \%$ \\
\hline Calcisol & Cambisol (Hyperautric) & $0 \%$ & $8 \%$ & $1 \%$ & $17 \%$ & $8 \%$ & $1 \%$ & $12 \%$ & $15 \%$ & $11 \%$ & $13 \%$ & $27 \%$ \\
\hline Calcosol & Cambisol (Calcaric) & $0 \%$ & $10 \%$ & $0.4 \%$ & $14 \%$ & $6 \%$ & $0.4 \%$ & $10 \%$ & $3 \%$ & $6 \%$ & $6 \%$ & $13 \%$ \\
\hline Colluviosol & RSG (Colluvic) & $1 \%$ & $3 \%$ & $2 \%$ & $7 \%$ & $2 \%$ & $3 \%$ & $6 \%$ & $0 \%$ & $28 \%$ & $0.4 \%$ & $0 \%$ \\
\hline Dolomitisol & Cambisol (Dolomitic) & $0 \%$ & $0 \%$ & $0 \%$ & $0 \%$ & $0 \%$ & $0 \%$ & $0 \%$ & $1 \%$ & $0 \%$ & $0 \%$ & $7 \%$ \\
\hline Fluviosol & Fluviosol & $0 \%$ & $15 \%$ & $1 \%$ & $0 \%$ & $1 \%$ & $1 \%$ & $2 \%$ & $1 \%$ & $17 \%$ & $3 \%$ & $0 \%$ \\
\hline Histosol & Histosol & $0 \%$ & $0.2 \%$ & $0 \%$ & $0 \%$ & $0.1 \%$ & $0 \%$ & $0 \%$ & $0 \%$ & $0 \%$ & $0 \%$ & $0 \%$ \\
\hline Lithosol & Leptosol & $0 \%$ & $0.3 \%$ & $1 \%$ & $0 \%$ & $0.1 \%$ & $2 \%$ & $3 \%$ & $3 \%$ & $0 \%$ & $0 \%$ & $13 \%$ \\
\hline Luvisol & Luvisol & $2 \%$ & $6 \%$ & $0.2 \%$ & $4 \%$ & $14 \%$ & $3 \%$ & $2 \%$ & $6 \%$ & $11 \%$ & $6 \%$ & $0 \%$ \\
\hline Neoluvisol & Cambisol (Luvic) & $9 \%$ & $9 \%$ & $3 \%$ & $9 \%$ & $11 \%$ & $2 \%$ & $3 \%$ & $12 \%$ & $6 \%$ & $9 \%$ & $0 \%$ \\
\hline Organosol & Umbrisol (Folic) & $0 \%$ & $0.3 \%$ & $0.2 \%$ & $6 \%$ & $0 \%$ & $1 \%$ & $6 \%$ & $4 \%$ & $0 \%$ & $0 \%$ & $0 \%$ \\
\hline Pelosol & Regosol (Clavic) & $0 \%$ & $3 \%$ & $0 \%$ & $1 \%$ & $2 \%$ & $0 \%$ & $0 \%$ & $0 \%$ & $0 \%$ & $0 \%$ & $0 \%$ \\
\hline Peyrosol & suffix qualifier Episkeletic & $0 \%$ & $0.3 \%$ & $3 \%$ & $1 \%$ & $1 \%$ & $0 \%$ & $1 \%$ & $5 \%$ & $0.0 \%$ & $0.4 \%$ & $0 \%$ \\
\hline Planosol & Planosol & $0 \%$ & $1 \%$ & $0 \%$ & $0 \%$ & $6 \%$ & $0 \%$ & $0 \%$ & $0 \%$ & $0 \%$ & $0.4 \%$ & $0 \%$ \\
\hline Podzosol & Podzol & $17 \%$ & $3 \%$ & $22 \%$ & $1 \%$ & $14 \%$ & $16 \%$ & $7 \%$ & $5 \%$ & $0 \%$ & $11 \%$ & $0 \%$ \\
\hline Rankosol & Leptosol & $5 \%$ & $0.3 \%$ & $3 \%$ & $0 \%$ & $0.2 \%$ & $6 \%$ & $2 \%$ & $2 \%$ & $0 \%$ & $0 \%$ & $7 \%$ \\
\hline Redoxisol & Stagnosol & $7 \%$ & $3 \%$ & $0.4 \%$ & $0 \%$ & $5 \%$ & $1 \%$ & $1 \%$ & $0 \%$ & $0 \%$ & $4 \%$ & $0 \%$ \\
\hline Reductisol & Gleysol & $1 \%$ & $3 \%$ & $1 \%$ & $1 \%$ & $1 \%$ & $0.4 \%$ & $1 \%$ & $0 \%$ & $0 \%$ & $4 \%$ & $0 \%$ \\
\hline Regosol & Regosol & $0 \%$ & $0.3 \%$ & $0 \%$ & $0 \%$ & $0 \%$ & $0 \%$ & $0.2 \%$ & $0 \%$ & $0 \%$ & $1 \%$ & $7 \%$ \\
\hline Rendisol & Leptosol (Rendzic) & $0 \%$ & $1 \%$ & $0.2 \%$ & $6 \%$ & $1 \%$ & $0.4 \%$ & $3 \%$ & $1 \%$ & $6 \%$ & $2 \%$ & $0 \%$ \\
\hline Rendosol & Leptosol (Rendzic) & $0 \%$ & $5 \%$ & $0.2 \%$ & $6 \%$ & $3 \%$ & $0 \%$ & $5 \%$ & $1 \%$ & $0 \%$ & $2 \%$ & $20 \%$ \\
\hline
\end{tabular}


630

Appendix. Codes and names of woody plant species used for RDA analysis

\begin{tabular}{|c|c|}
\hline Aal & Abies alba \\
\hline Agr & Abies grandis \\
\hline Aca & Acer campestre \\
\hline Amo & Acer monspessulanum \\
\hline Ama & Acer monspessulanum subsp. martinii \\
\hline Ane & Acer negundo \\
\hline Aop & Acer opalus \\
\hline Apl & Acer platanoides \\
\hline Aps & Acer pseudoplatanus \\
\hline Ahi & Aesculus hippocastanum \\
\hline Aco & Alnus cordata \\
\hline $\mathrm{Agl}$ & Alnus glutinosa \\
\hline Ain & Alnus incana \\
\hline Bpe & Betula pendula \\
\hline Bsp & Betula sp. \\
\hline Cbe & Carpinus betulus \\
\hline Csa & Castanea sativa \\
\hline Cat & Cedrus atlantica \\
\hline Cse & Cupressus sempervirens \\
\hline Fsy & Fagus sylvatica \\
\hline Fan & Fraxinus angustifolia \\
\hline Fox & Fraxinus angustifolia subsp. oxycarpa \\
\hline Fex & Fraxinus excelsior \\
\hline For & Fraxinus ornus \\
\hline Iaq & Ilex aquifolium \\
\hline Jni & Juglans nigra \\
\hline Jre & Juglans regia \\
\hline Lde & Larix decidua \\
\hline Ltu & Liriodendron tulipifera \\
\hline Msy & Malus sylvestris \\
\hline Oca & Ostrya carpinifolia \\
\hline Pab & Picea abies \\
\hline Psi & Picea sitchensis \\
\hline Pce & Pinus cembra \\
\hline Pha & Pinus halepensis \\
\hline Pni & Pinus nigra \\
\hline $\mathrm{Pla}$ & Pinus nigra subsp. laricio \\
\hline Pns & Pinus nigra subsp. nigra \\
\hline Ppi & Pinus pinaster \\
\hline Ppa & Pinus pinea \\
\hline Pst & Pinus strobus \\
\hline Psy & Pinus sylvestris \\
\hline Pun & Pinus uncinata \\
\hline $\mathrm{Pac}$ & Platanus acerifolia \\
\hline Psp & Platanus sp. \\
\hline Pal & Populus alba \\
\hline Pca & Populus canescens \\
\hline Pna & Populus nigra \\
\hline Pos & Populus sp. \\
\hline Ptr & Populus tremula \\
\hline Pxc & Populus $x$-canadensis \\
\hline Pav & Prunus avium \\
\hline Prs & Prunus sp. \\
\hline Pme & Pseudotsuga menziesii \\
\hline Pco & Pyrus communis \\
\hline Ppy & Pyrus pyraster \\
\hline Pys & Pyrus sp. \\
\hline Qce & Quercus cerris \\
\hline Qhu & Quercus humilis \\
\hline Qil & Quercus ilex \\
\hline Qpe & Quercus petraea \\
\hline Qpy & Quercus pyrenaica \\
\hline Qro & Quercus robur \\
\hline Qru & Quercus rubra \\
\hline Qsp & Quercus sp. \\
\hline Qsu & Quercus suber \\
\hline Qca & Quercus $x$-calvescens \\
\hline Rps & Robinia pseudoacacia \\
\hline Sal & Salix alba \\
\hline Sca & Salix caprea \\
\hline Ssp & Salix sp. \\
\hline Sar & Sorbus aria \\
\hline Sau & Sorbus aucuparia \\
\hline Sdo & Sorbus domestica \\
\hline Sla & Sorbus latifolia \\
\hline Smo & Sorbus mougeotii \\
\hline Ssp & Sorbus sp. \\
\hline Sto & Sorbus torminalis \\
\hline Sin & Sorbus $x$-intermedia \\
\hline Tba & Taxus baccata \\
\hline $\mathrm{Tpl}$ & Thuja plicata \\
\hline Tco & Tilia cordata \\
\hline $\mathrm{Tpl}$ & Tilia platyphyllos \\
\hline Tvu & Tilia $x$-vulgaris \\
\hline Ugl & Ulmus glabra \\
\hline Ula & Ulmus laevis \\
\hline Umi & Ulmus minor \\
\hline Usp & Ulmus sp. \\
\hline
\end{tabular}


631

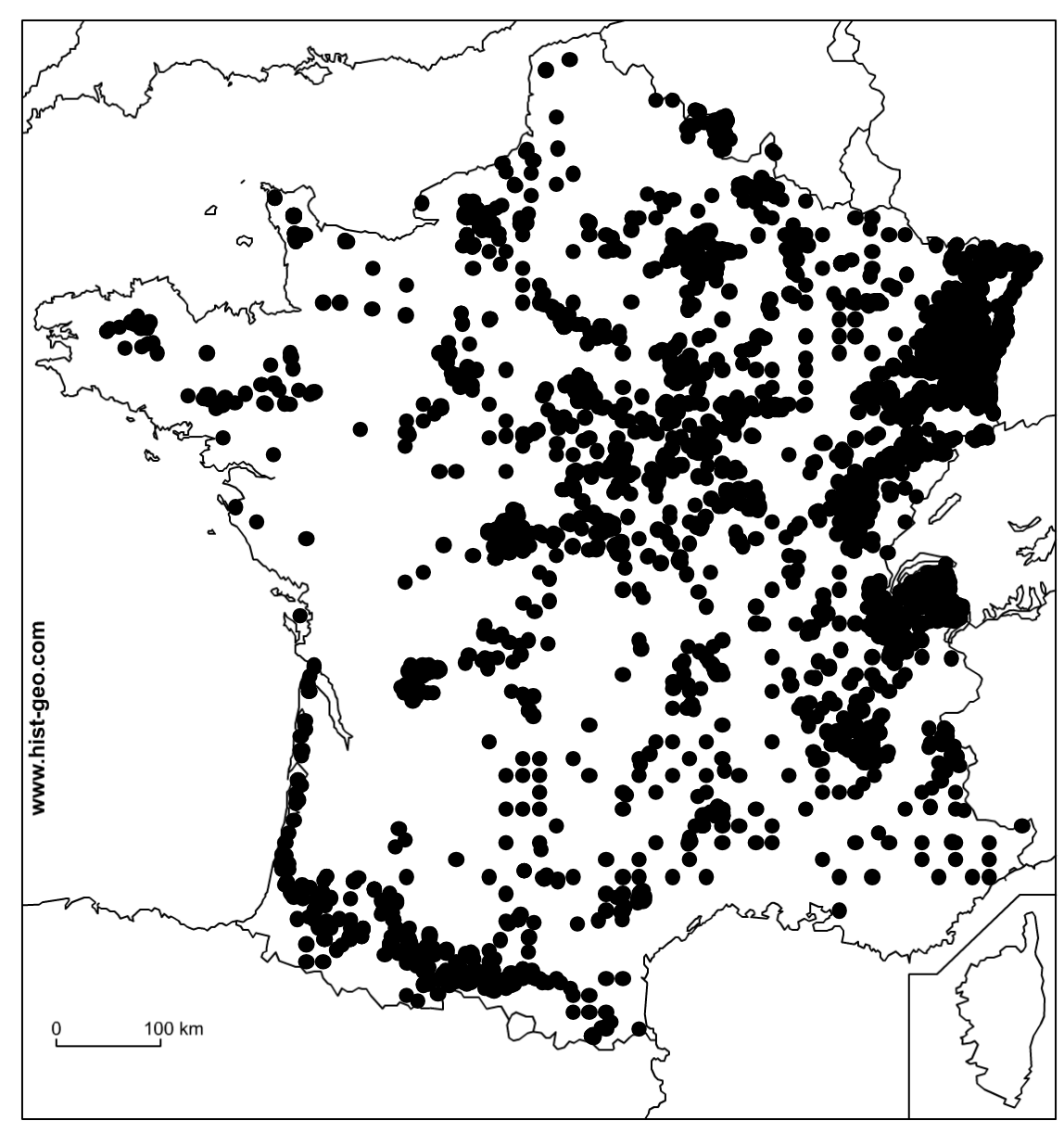

$632 \quad$ Fig. 1 


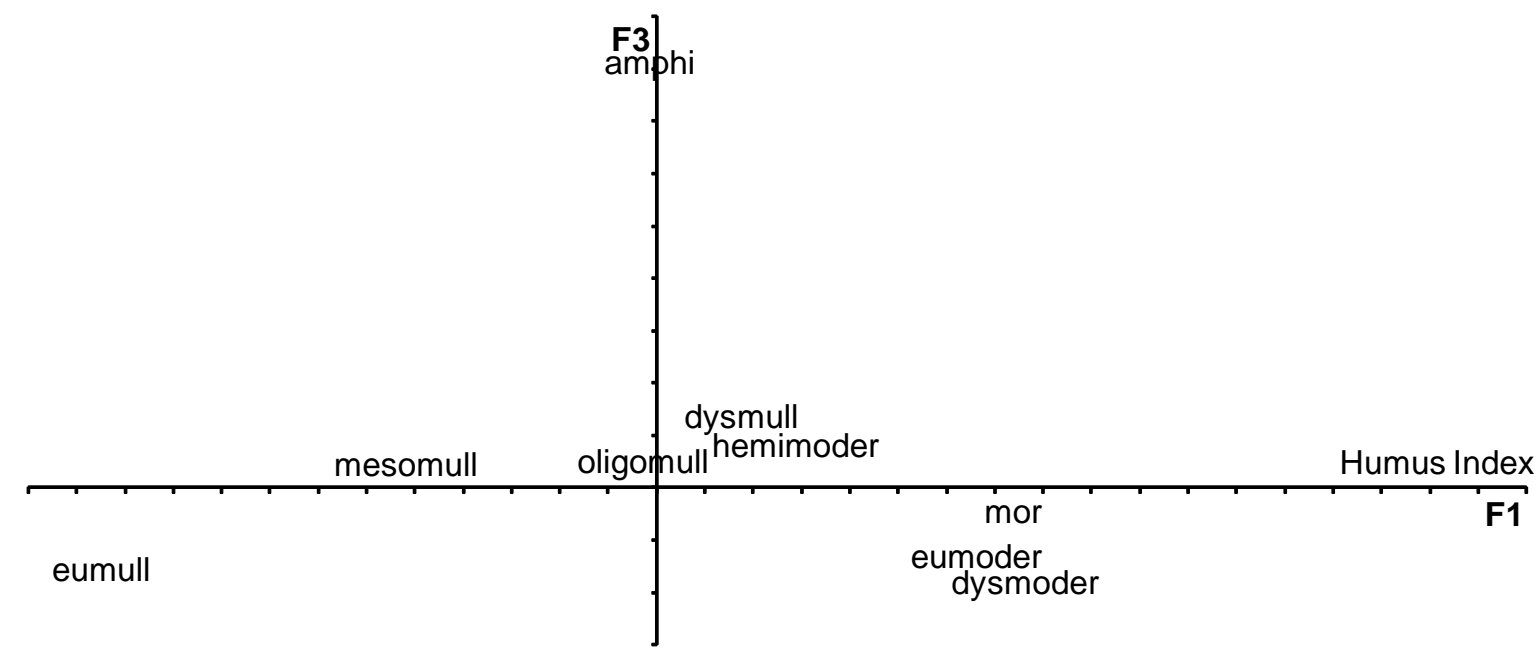

634

635 Fig. 2 


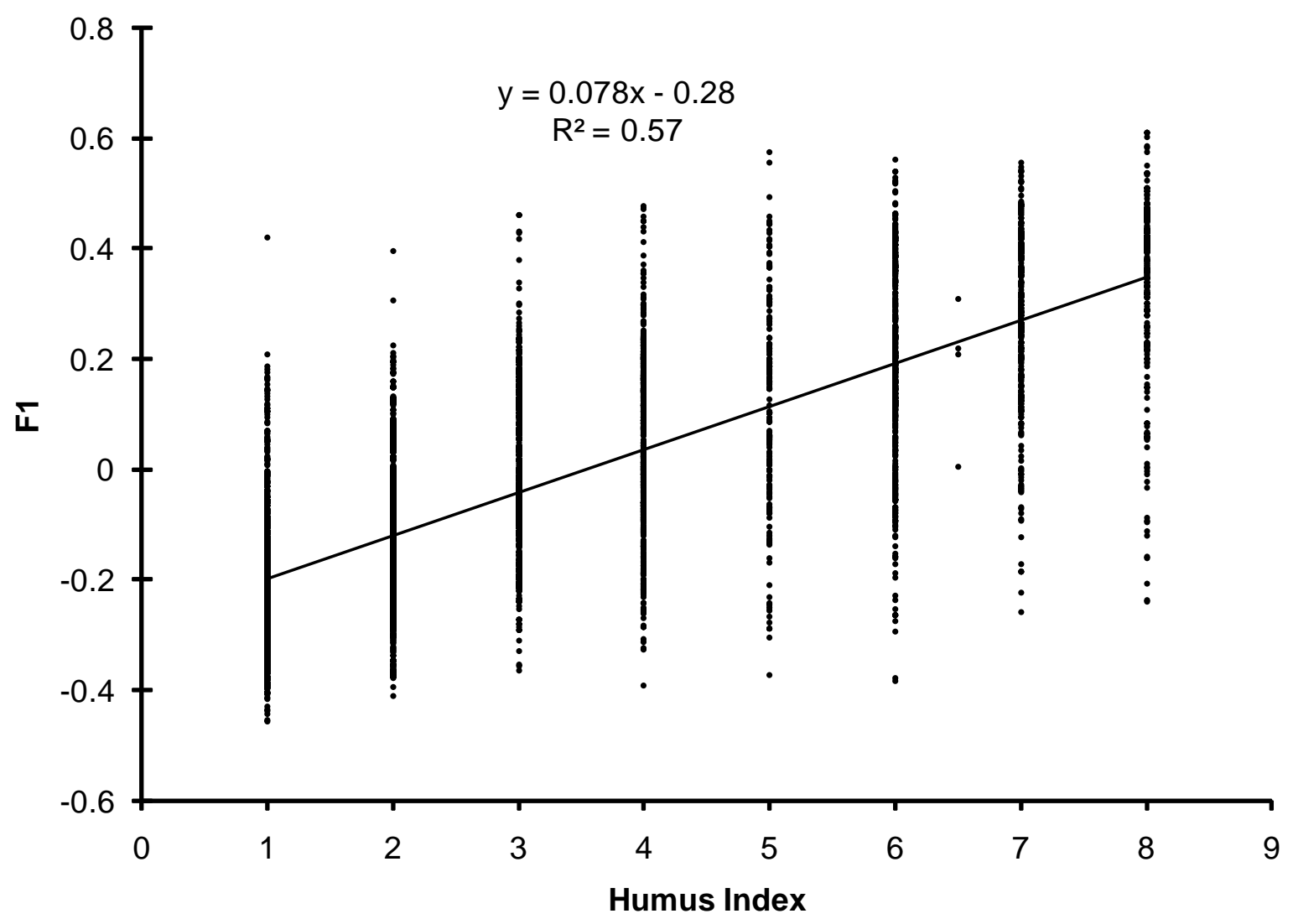

637

$638 \quad$ Fig. 3

639 


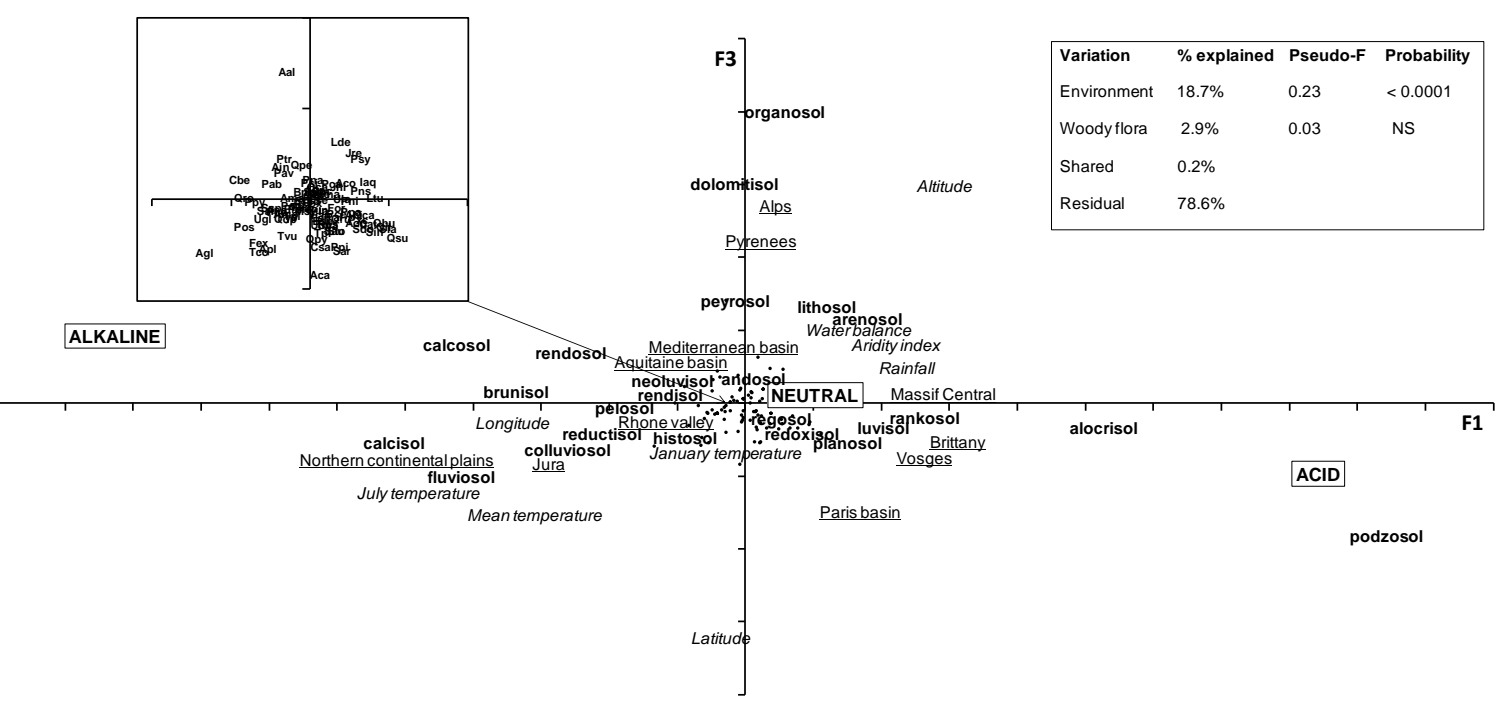

$641 \quad$ Fig. 4 

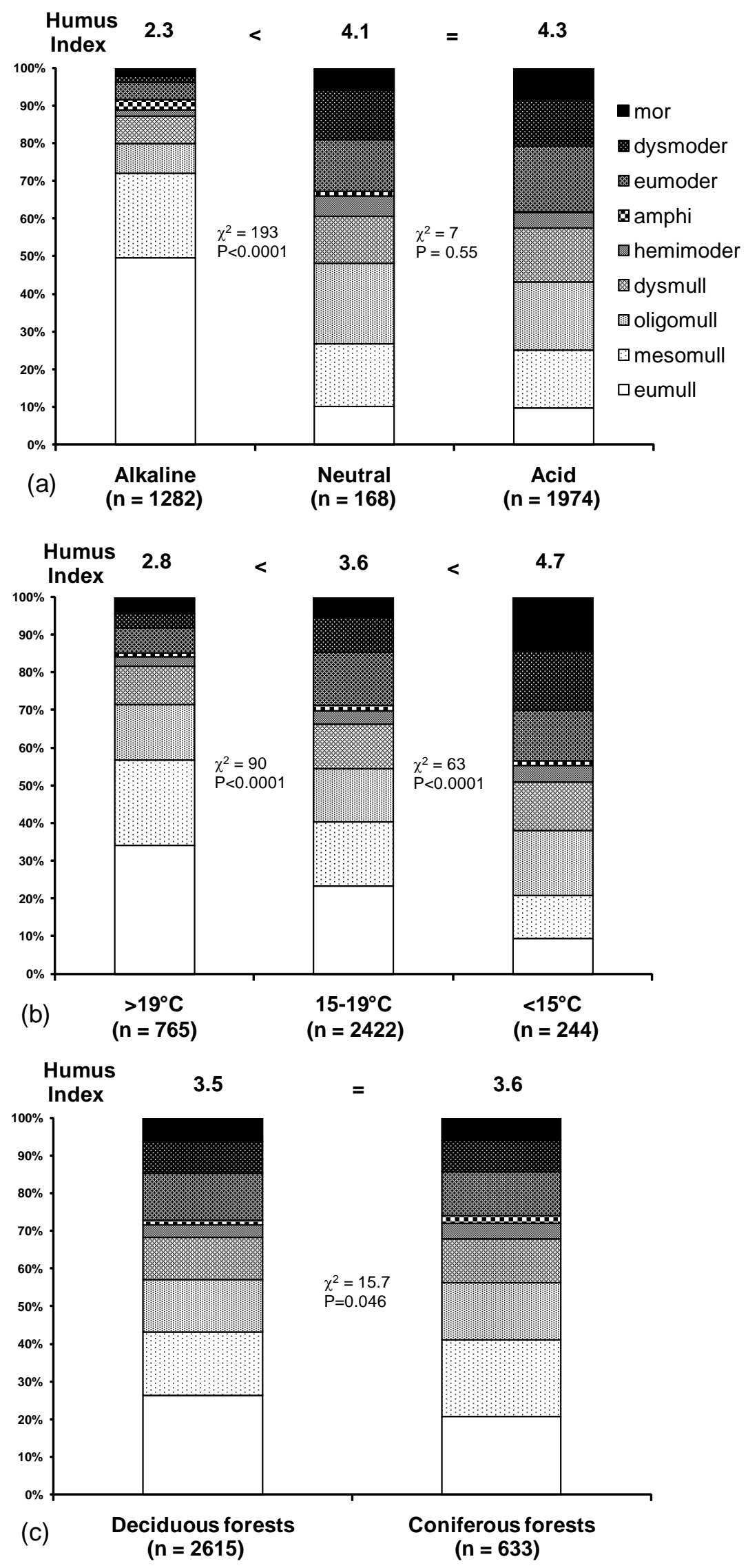

Fig. 5 